\title{
The Bioenergetics of Deposit and Utilization of Stored Energy in the Common Vole
}

\author{
J. JAGOSZ, A. GÓRECKI \& M. POZZI-CABAJ
}

\begin{abstract}
Jagosz J., Górecki A. \& Pozzi-Cabaj M., 1979: The bioenergetics of deposit and utilization of stored energy in the common vole. Acta theriol., 24, 28: 391-397 [With 3 Tables]

Measurements were made of average daily metabolism rate and of food consumption and utilization in common voles, Microtus arvalis ( $\mathrm{Pa} 11 \mathrm{as}, 1779)$. The studies were carried out on control animals at a temperature of $20^{\circ} \mathrm{C}$, then the animals were kept fasting for 48 hours and later supplied with food of known composition and caloric value. Oxygen consumption was respectively for these groups: 0.48; 0.56; $0.51 \mathrm{kcal} / \mathrm{g} \times \mathrm{day}$, and food assimilation in control animals 0.54 , in animals fed after fasting $0.75 \mathrm{kcal} / \mathrm{g} \times$ day. Calculation was made from difference in the voles' body weight, and their respiration and food assimilation, of the costs of depositing 1 gram of body tissue as 8.572 $\mathrm{kcal}$, the energy value of production itself forming $7.610 \mathrm{kcal}$ of this figure. Energy gain from burning 1 gram of the animal's own tissues calculated analogically was $5.583 \mathrm{kcal}$.

[Dept. Animal Ecol., Jagiellonian Univ., Krupnicza 50, 30-060 Kraków, Poland].
\end{abstract}

\section{INTRODUCTION}

Although of importance to both animal husbandry and ecology, little is known about the cost of depositing and utilizing stored energy in animals. This factor affects the individuals' chances of survival and also plays a very important role in estimating energy flow through populations.

This index was studied in the common vole, Microtus arvalis ( $\mathrm{P}$ a $11-$ a s, 1779). These rodents, dominating in agrocenoses, are of outstanding economic significance, particularly during outbreaking year. Choice of the vole for such studies was also influenced by the fact that there is already a considerable amount of data on its bioenergetic and population parameters.

\section{MATERIAL AND METHODS}

Adult voles were kept in a laboratory at a temperature of $20^{\circ} \mathrm{C}$, with normal light rhythm, and all measurements were made at this temperature. The experiment consisted of three consecutive basic series: (1) control, (2) animals kept 
fasting for 48 hours, (3) animals fed after their fast. The results of the study by Kostelecka-Myrcha \& Myrcha (1964) suggest that although plant food remains in the vole's stomach for over 10 hours, and cereal seeds for even longer, about $30 \%$ of the voles die if kept fasting for longer than 48 hours. A very considerable drop in the animals' body weight occurred as the result of the 48-hour fast used in these experiments.

In all the series of experiments, examination was made of the average daily metabolism rate $(A D M R)$ of voles, using a Morrison system respirometer (M o r r ison \& Grodziński, 1975). $A D M R$ was determined for 36 animals, involving the three series of measurements jointly. For each series of measurements examination was made of the respiratory coefficient $(R Q)$ in several voles in the open system "Spirolyt « respirometer.

\section{Table 1}

Chemical composition of diets used in experiments (in per cent of dry weight).

\begin{tabular}{rrrrrr}
\hline $\begin{array}{c}\text { Diets } \\
\text { in serie }\end{array}$ & Protein & Fat & $\begin{array}{c}\text { Carbo- } \\
\text { hydrates }\end{array}$ & Ash & $\begin{array}{c}\text { Caloric } \\
\text { value } \\
\text { in cal/g }\end{array}$ \\
\hline I & 9.81 & 15.40 & 71.59 & 3.20 & 4801 \\
II & 13.12 & 12.20 & 70.88 & 3.80 & 4578 \\
III & 11.37 & 15.03 & 69.10 & 4.50 & 5095 \\
\hline
\end{tabular}

Consumption, digestion and assimilation of food were determined parallely to measurements of metabolism. Over the whole cycle of experiments the voles were supplied with specially prepared food consisting of ground hazel nuts and wheat grains. The food was prepared immediately before each experiment, and consequently the composition of the various portions differed slightly in respect of fat, protein content and caloric value (Table 1). Although this is not food typical of voles, it was chosen as the result of experiments and used, as it ensured a rapid gain in the voles' body weight.

The energy value of food, faeces and urine was defined by burning them in a calorimetric bomb (G ó r e cki, 1975).

\section{RESULTS}

\subsection{Average Daily Metabolism Rate}

The daily metabolic rates of the study groups of voles have been compared in Table 2. The animals' body weights were fairly similar in all the groups, and the coefficient of variation highest in voles fed after fasting - approximately $25 \%$, but none of the average body weights of any group differed statistically significantly. Oxygen consumption was converted to calories, using the previously defined $R Q$ of 0.8 for the control group and the group fed after fasting (the caloric 
equivalent of 1 litre of oxygen was thus $4.8 \mathrm{kcal}$, and 0.7 for fasting voles i.e., $4.7 \mathrm{kcal} / \mathrm{litre})$. Oxygen consumption calculated in this way was $0.480^{-} \mathrm{kcal} / \mathrm{g} \times$ day in the control group, but is about $16 \%$ higher in the fasting animals, probably as the result of their increased activity. Differences in respiration value for the two groups are on the borderine of statistical significance $(P \approx 0.05)$. The metabolism of animals fed after fasting has an intermediate value $-0.509 \mathrm{kcal} / \mathrm{g} \times$ day, and it also fails to differ statistically from the two previous values. The coefficient of variation in the two groups consuming food was about $15.5 \%$, and in the fasting group $23 \%$.

Table 2

Oxygen consumption levels of control and experimental animals.

\begin{tabular}{|c|c|c|c|}
\hline Item & Control & Fasted & $\begin{array}{l}\text { Fed after } \\
48 \text { hrs fasting }\end{array}$ \\
\hline $\mathrm{N}$ & 13 & 13 & 10 \\
\hline Body wt in $g \pm S D$ & $26.3 \pm 3.8$ & $28.3 \pm 3.6$ & $25.3 \pm 6.4$ \\
\hline $\mathrm{ccm} / \mathrm{g} \times \mathrm{hr} \pm \mathrm{SD}$ & $4.16 \pm 0.63$ & $4.95 \pm 0.99$ & $4.41 \pm 0.71$ \\
\hline $\mathrm{kcal} / \mathrm{g} \times$ day & 0.480 & 0.559 & 0.509 \\
\hline $\mathrm{kcal} /$ animal $\times$ day & 12.630 & 15.801 & 12.877 \\
\hline $\begin{array}{l}\mathrm{kcal} / \mathrm{kg} 0.75 \times \text { day } \\
A D M R \text { (in } \mathrm{ccm} / \mathrm{g} \times \mathrm{hr} \text { ) }\end{array}$ & 195.0 & 231.6 & 201.9 \\
\hline as a function of $b$. wt. (in g) & $10.3 W^{-0.278}$ & $9.3 W-0.201$ & $24.6 W^{-0.545}$ \\
\hline
\end{tabular}

Oxygen consumption expressed in metabolic units of body weight (K l e iber, 1961) varied within a narrow range from 195 to $232 \mathrm{kcal} /$ $\mathrm{kg}^{0.73} \times$ day (Table 2). Variation in the body weight of the voles examined permitted of calculating the relation between metabolism and body weight (Table 2). The most distinct relation between $A D M R$ and body weight can be seen in animals fed after fasting $(b=-0.545)$. This is probably connected with the maximum range of body weight in this group, as is shown by the greatest standard deviation (Table 2).

\subsection{Consumption and Utilization of Food}

Voles in the control group consumed from 5 to $9 \mathrm{~g}$ of food (average $7.03 \mathrm{~g}$ ) over a 24 -hour period, that is, about $16.5 \mathrm{kcal} / \mathrm{animal} \times$ day (Table 3). Animals fed after fasting for 48 hours consumed from 2 to $6 \mathrm{~g}$ of food, but of higher caloric value (food III - Table 1), and thus consumed about $22.4 \mathrm{kcal} / \mathrm{animal} \times$ day with their food (Table 3 ). After calculating energy loss due to excreting faeces and urine, assimilation in 
the control animals was about $0.54 \mathrm{kcal} / \mathrm{g} \times$ day, and as much as $0.747 \mathrm{kcal} / \mathrm{g} \times$ day in the group of voles fed after fasting (Table 3 ).

Table 3

Consumption and utilization of food by common voles.

\begin{tabular}{llc}
\hline \multicolumn{1}{c}{ Item } & \multicolumn{1}{c}{ Control } & Fed after fasting (10) \\
\hline Body wt. in $\mathrm{g} \pm \mathrm{SD}$ & $26.3 \pm 3.8$ & $25.3 \pm 6.4$ \\
Consumption kcal/anim $\times$ day $\pm \mathrm{SD}$ & $16.55 \pm 6.05$ & $22.36 \pm 9.68$ \\
Coefficient of digestibility in $\% \%$ & 86.7 & 88.9 \\
Assimilation: & & \\
Coefficient in $\% \%$ & 82.2 & 84.4 \\
$\mathrm{kcal} / \mathrm{g} \times$ day & 0.537 & 0.747 \\
$\mathrm{kcal} / \mathrm{anim} . \times$ day & 14.135 & 18.889 \\
$\mathrm{kcal} / \mathrm{kg} 0.75 \times$ day & 214.2 & 294.1 \\
\hline
\end{tabular}

\subsection{Costs of Deposition}

Voles fed after a 48-hour fast exhibited an average increase in body weight of $0.79 \pm$ (SD) $0.1 \mathrm{~g}$ per day. Energy costs of production were calculated from the gain in body weight and from the differences in respiration and assimilation values. Respiration was $12.877 \mathrm{kcal} / \mathrm{animal} X$ day (Table 2), and food assimilation $18.889 \mathrm{kcal} /$ animal $\times$ day (Table 3 ). An average animal therefore had $6.012 \mathrm{kcal} /$ day at its disposal. The value $(A-R=P)$, calculated in this way, represents the value of energy deposit. Costs of deposition are, however, slightly increased by the energy required for this process included in respiration measurement. In order to calculate the deposition costs the following equation must be used:

$$
D C=P+\left(R_{\text {dep }}-R_{\text {control }}\right)
$$

when: $D C$ - deposit costs, $P$ - energy value of production, $R_{\text {dep }}$ - animals' metabolism during deposit, deposition, $R_{\text {control }}$ - metabolism of control animals.

Use has been made here of the respiration value for control and fed animals, the value being expressed in $\mathrm{kcal} / \mathrm{g}$ of body weight $\times 24$ hours. In connection with the slight $(1 \mathrm{~g})$ difference in body weights this last value for fed voles was multiplied by the value of body weight in control voles $(26.3 \mathrm{~g})$. Respiration value for the whole animal obtained in this way was $13.39 \mathrm{kcal} /$ day. Thus

$$
R_{\text {dep }}(13.39 \mathrm{kcal} / \mathrm{day})-R_{\text {contr }}(12.63 \mathrm{kcal} / \mathrm{day})-0.76 \mathrm{kcal} / \mathrm{animal} \times \text { day }
$$

If this value is added to that calculated previously $(6.012 \mathrm{kcal} / \mathrm{day})$. 
then deposition cost of $0.79 \mathrm{~g}$ of tissues per day $6.772 \mathrm{kcal}$. Efficiency of the deposition is thus unusually high, since it is as much as $88.8 \%$. Such high efficiency suggests that the deposit in short intervale of time may apply chiefly to fat. During a 24-hour period the voles increased their body weight by $0.78 \mathrm{~g}$, and thus costs of depositing 1 gram are $8.572 \mathrm{kcal}$, the energy value of production itself being $7.610 \mathrm{kcal}$.

\subsection{Utilization of Energy Deposited in the Form of the Animal's own Tissues}

After fasting for 48 hours voles lost on an average 2.83 ( $\pm 0.68 \mathrm{~g}$ ) of body weight per day. As the animals did not consume any food during this time the whole of respiration took place comes from previously deposited tissues. If respiration is $15.801 \mathrm{kcal} / \mathrm{animal} \times$ day (Table 2), then the voles obtained on an average $5.583 \mathrm{kcal}$ from burning $1 \mathrm{~g}$ of tissues.

\section{DISCUSSION}

Food forms the only source from which animals draw energy for satisfying all their vital needs. In mammals this energy is used to maintain a constant high body temperature, the action of motor muscles and function of the respiratory apparatus, alimentary system, circulation, nervous system etc. (K l e i b e r, 1961). In addition the animal organism uses energy continuously for building and regenerating tissues and for reproduction. During periods of food deprivation all these costs must be met by energy released by burning the animal's own tissues.

Deposition costs obtained in the present study are far lower than those given by Kielanowski (1965), who calculated that about 14 kcal were required to deposit $1 \mathrm{~g}$, but he assumed that animals deposited fat only. The paper by S a w i cka-Ka p u sta (1974) shows that both increase in body weight, and also its winter depression is the resultant of fundamental changes in all the basic components of the body in rodents. Over short periods of time, however, variations may apply almost solely to fat, hence the deposit value obtained in the present study may be taken as highly probable. Similar costs of deposit were obtained by K e ndeigh et al. (1969) for birds, the figure being about $6 \mathrm{kcal} / \mathrm{gram}$ of increase in body weight.

According to $\mathrm{K}$ in g \& F a r n e r (1961), a decrease in a bird's biomass of 1 gram corresponds to the equivalent of approximately $7 \mathrm{kcal}$. In the case of birds which varied in body weight during experiments lasting several days $\mathrm{K}$ e n d e ig h et al. (1969) used a coefficient of $3 \mathrm{kcal}$ with loss of 1 gram of body weight. The amount of energy obtained in the 
present study from burning $1 \mathrm{~g}$ of the vole tissue $(5.583 \mathrm{kcal})$ comes between the two values given above.

When costs of deposition are compared with utilization of previously deposited energy it can be seen that they differ by only about $35 \%$. During short periods of fasting, which form a fairly frequent phenomenon in small homoiothermal animals, they manage quite well by obtaining sufficient amounts of energy to satisfy their current needs from the supply deposited in tissues.

With ambient temperatures below the thermoneutral zone the whole of the energy obtained by burning tissues may be fully used, since even the heat generated in all these processes is included in heat production for thermoregulation.

$\mathrm{D}$ ro ż d ż et al. (1972) state that an adult vole has up to $50 \%$ fat in dry body mass, that is, about $16 \%$ in its biomass. From this amount it is able to utilize at least $10 \%$, that is, about $2 \mathrm{~g}$ of fat, by burning which the animals can obtain about $18 \mathrm{kcal}$. This amount of energy is sufficient for an animal to satisfy its basic energy needs for two days at most.

It is obvious that this method of obtaining energy can only be used over very short periods of time and that the animal cannot resort to it too frequently, since after a period of fasting the lost energy stores must be deposited again.

\section{REFERENCES}

1. Góre ck i A., 1975: The adiabatic bomb calorimeter. [In: wMethods for ecological bioenergetics«, Eds. W. Grodziński, R. Z. Klekowski, A. Duncan]. Cambridge Univ. Press: 281-288. Oxford, London, Edinburgh.

2. Kendeigh L., Kontogiannis J. E., M a z a A. \& Rohr R. R., 1969: Environmental regulation of food intake by birds. Comp. Biochem. Physiol., 39: $941-957$.

3. Kielanowski J., 1965: Estimates of the energy cost of protein deposition in growing animals. [In: »Energy metabolism«, Ed. K. L. Blaxter]. Academic Press: 13-20. London, New York.

4. King J. R. \& F a rne r D. S., 1961: Energy metabolism, thermoregulation and body temperature. [In: "Biology and comparative physiology of birds«, Ed. A. J. Marshall]. Academic Press: 215-288. New York, London.

5. Kostelecka-Myrcha A. \& Myrcha A., 1964: The rate of passage of foodstuffs through the alimentary tract of certain Microtidae under laboratory conditions. Acta theriol., 9, 4: 37-53.

6. Kleiber M., 1961: The fire of life - an introduction to animal energetics. J. Wiley: $1-454$. New York, London.

7. Morrison P. R. \& Grodziński W., 1968: Morrison respirometer and determination of ADMR. [In: "Methods of Ecological Bioenergetics«, Eds. W. Grodziński and R. Klekowski. Państw. Wyd. Nauk.: 153-163. Warszawa-Kraków.

8. Sawicka-Kapusta K., 1974: Changes in the gross body composition and 
energy values of the bank vole during their postnatal development. Acta theriol., 19, 3: 27-54.

9. Sawicka-Kapusta K., Dobrołęcka M., DrożdżA. \& Tertil R., 1975: Bioenergetic parameters of experimental groups of common vole (Microtus arvalis (Pall. 1779)). Ekol. pol., 23, 2: 347-365.

Accepted, March 29, 1979.

J. JAGOSZ, A. GORECKI i M. POZZI-CABAJ

\section{BIOENERGETYKA DEPOZYCJI I WYKORZYSTANIA ZAPASOW ENERGETYCZNYCH U NORNIKA ZWYCZAJNEGO}

\section{Streszczenie}

U nornika zwyczajnego (Microtus arvalis $\mathrm{Pallas}$, 1779) przeprowadzono pomiary średniego metabolizmu dobowego, oraz konsumpcji i wykorzystania pokarmów. Badania prowadzono w $20^{\circ} \mathrm{C}$ u zwierząt kontrolnych, następnie głodzonych 48 godzin i ponownie karmionych paszą o znanym składzie i kaloryczności (Tabela 1). Zużycie tlenu wynosiło u tych grup - kolejno: $0.48,0,56$ i $0,51 \mathrm{kcal} / \mathrm{g} \times$ doba, zaś asymilacja pokarmu u zwierząt kontrolnych wyniosła 0,54 , natomiast u karmionych po głodzeniu odpowiednio 0,75 (Tabela 2). Ze zmian w ciężarach ciała norników, oraz ich respiracji i asymilacji pokarmu wyliczono koszty depozycji 1 grama tkanek ciała na $8,572 \mathrm{kcal}$, w czym wartość energetyczna samej produkcji stanowi $7,610 \mathrm{kcal}$ (Tabela 3). Analogicznie wyliczono zysk energetyczny ze spalenia 1 grama własnych tkanek, który wynosi 5,583 kcal. 